\title{
Functional approach to songs in film translation: Challenges and compromises
}

\author{
Olena Pidhrushna ${ }^{1}$ \\ ${ }^{1}$ Taras Shevchenko National University of Kyiv, 64/13, Volodymyrska Street, Kyiv, Ukraine
}

\begin{abstract}
Translation of songs used in films comprises a unique phenomenon since it supposes to take into account an interdependence of two multimodal systems and their components. The challenges associated with the translation of songs in films manifest themselves both on the level of an internal system of a song (interconnection of lyrics and music on prosodic, poetic and semantic levels) and external relations of a song and a film it is immersed into (visual, audial and semantic levels of interaction). The article attempts to consider translation of songs in films within the frameworks of the functional approach and states that the pragmatic function and communicative purpose of a song in a film are translation dominants. The paper suggests and discusses five levels of correspondence between the source song and target song in film translation, i.e., pragmatic, semantic, stylistic, cinematic, and aesthetic. It determines a correlation between translation technique used in the recreation of lyrics (zero translation, interlinear translation and adaptation) and potentially achievable levels of correspondence.
\end{abstract}

\section{Introduction}

Nowadays the problems of audio-visual translation are extremely topical taking into account both the growth of the foreign film production industry and an intense domestic demand for the productions. The complexity and versatility of audio-visual translation draws the considerable attention of researchers worldwide (F. Chaume, J. Diaz-Cintas, P. Orero, L. Perez-Gonzalez). Nonetheless, in Ukraine, the practice of film translation has left the theoretical comprehension of the issue far behind. However, in the recent decades, the gap between the theory and practice of the English-Ukrainian audio-visual translation has narrowed due to the numerous studies within the field and its particular issues, e.g., rendering of the culture-bound lexical units, words of different registers, the problem of the textual and visual layers interconnection and interdependence, the problem of synchronization, etc. based on various films, series and serials (V. Konkyliovskyi, T. Lukianova, A. Melnyk).

Still, several issues haven't received enough attention both in domestic and foreign translation studies. One of such issues is the role and place of songs in film translation. To say that musical compositions have never been considered as the objects of translation studies would be an erroneous statement. There is a range of works devoted to libretto translation in opera performances, popular songs translation and translation of songs for live performances

*Corresponding author: elenapdgr@knu.ua 
(R. Apter, J. Franzon, K. Kaindl, P. Low). Some of the most remarkable ones are outlined in Bosseaux [1]. However, a problem of song translation in films is mostly narrowed to the individual case studies based on songs in animated films, screen versions of musicals or other specific cases within particular language pairs (P. Alonso, S. Aminoroaya, N. Bidasyuk, M. Gato, A. Pavliuk, Z. Poduholnikova).

This study aims to take a wider look at the role and function of songs in films and to clarify possible approaches to songs recreation in the foreign language. This paper examines the range of translation challenges and constraints associated with a song translation in films that derive from the multimodal nature of both texts. The research also intends to define the notion of adequacy applicable to song translation in films within the frameworks of the functional approach.

\section{Methods}

Research material comprises the songs in the English language used in films and serials released during the $21^{\text {st }}$ century and localized for the Ukrainian viewers. The preference is given to the contemporary films and series in order to examine relevant techniques employed in the Ukrainian translations of songs in films. For the purposes of this study, the films and series were not categorized by their genres, since the main focus is to reveal and discuss general tendencies of song translation in films. In order to define and describe fundamental difficulties related to the translation of songs in films, the analysis, generalization and classification of available theoretical data was carried out. The comparative analysis of source and target songs was conducted to reveal their correspondence on different levels and to draw a conclusion on the translation adequacy. Source and target lyrics were considered as parallel texts, however the multimodal nature of a song and its functioning within a film were taken into account in the process of comparative analysis.

Multimodal theory seems to be particularly helpful in a discussion of song translation in films. Multimodality is usually understood as an integration of different semiotic modes and/or sub-modes. The complex interconnection and interdependence of modes within the multimodal cohesion create the meaning of the unified whole. An important thing here is that the verbal mode - the language - is not given a preferential status [2, 182]. A film is an example of a multimodal text. It combines aural and visual semiotic modes, both verbal and non-verbal (e.g., dialogues, sound effects, images, captions, etc.). A song as a separate unit is a multimodal text as well. Basically, it combines verbal and non-verbal aural modes with additional visual modes, e.g., in live performances or video clips. The fact that the verbal and visual content are linked to the way a piece is played, sung and/or produced is crucial to film songs in particular [3, 65].

A rough visual representation of a song in a film (Fig.1) shows specifics of its functioning and interconnections between structural elements within a song and a film.

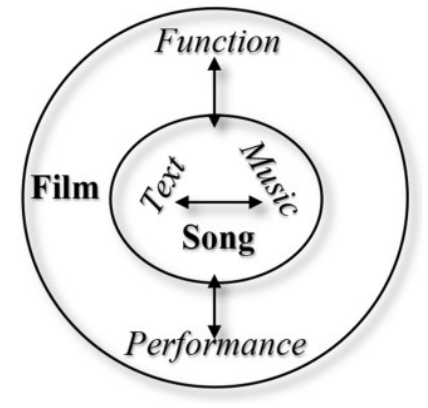

Fig. 1. A visual representation of a song in a film. 
Basically, it is the situation where one multimodal text (a song) is immersed into the setting of the other (a film). On the one hand, any song used in a film, regardless of its genre and origin, is a finalized individual musical work. It is a deliberate combination of lyrics (text) and sound (music). On the other hand, a song is an important aesthetic element of any cinematographic work. It communicates with the other semiotic systems of a film. As a part of the narrative, it is represented on screen in a specific way (performance) and is used with a specific aim (function). Thus, a song in film translation is considered as an independent musical composition with the predefined linguistic and extralinguistic features imposed by the requirements of a coherent entity - a film.

A process of multimodal text translation is usually referred to as "constrained translation", where each non-linguistic element constitutes the part of, adds to or modifies the general meaning, i.e., creates "constrains" by imposing its laws and conditions on the text $[4,363]$. Thus, the translation process is engaged into the whole multimodal system, otherwise the disregard of non-verbal modes would inevitably lead to the inadequate target language (TL) result. Thus, it is important to examine the challenges related to song translation in films.

\section{Constraints of song translation in films}

The number of challenges and constraints of song translation in films arises from its complex and multifaceted nature. The first challenge of song translation in general (and in films as well) lies in the interdependence of lyrics and music. In general, the biggest challenge of a song translation lies in the fact, that it is not about translation of the textual component lyrics - as a poem, but as the TL lyrics that would be singable when set to the source music. Music is a dominant element since in film translation there are usually little to no opportunities to change it. Franzon [5, 390] argues, that lyric displays a prosodic, poetic and emotional match to the music, which manifests itself in the text as specific rhythm, intonation, stress pattern (prosodic level); peculiar rhyme scheme, segmentation of stanza, location of keywords (poetic level); conveyed mood, associations, imagery (semanticreflexive level). Researches [6-8] prove that the creation of identical matches in the source text (ST) and target text (TT) does not guarantee an adequate translation of a song. The natural sounding (in terms of stress patterns, rhythmical structure and sound) of the TL lyrics is more preferable to the notional copying of the SL rhyme. Apart from the employment of a rhyme scheme different from the one employed in the source lyrics, there is a wide range of other stylistic means that can be used to produce a singable result in the TL, such as alliteration, assonance, etc. Some approaches to lyrics translation prioritise the music and content of a song, rather than the formal characteristics of the lyrics [9, 200]. Thus, minor faults, such as inconsequent rhythm, omissions or variations between times, neglect of separate unstressed syllables, slight violation of syntactic structure, repetitions and word order, can be justified. There are works devoted to the application of specific ways and techniques of recreating lyrics in songs, i.e., modulation, transposition, compensation, cultural adaptation, omission, use of additions to solve problems with rhythm, replacement of rhymes, etc. with a purpose to create a singable and performable target result, however, the issue goes beyond the purpose of this paper. Moreover, the translation practice shows, that creation of a singable target lyrics in film translation is not always required.

Another challenge lies in the correlation between a song and a video sequence. The video sequence in a film is a ready-made footage and can't be changed in the process of translation. There is a director's idea behind the place and way of a song performance in film. A film song is heard within a specific timeframe of a specific scene. Film songs can be diegetic (i.e., serve as a narration), or non-diegetic (i.e., serve as a background) [10, 82]. Both factors influence the translation strategy, as they shape the artistic purpose of the song, - narrative songs comprise the dialogues and monologues of the characters and contribute to 
"characterization and plot development" $[11,88]$, while background songs are used to emphasize, strengthen or soften emotional impact of a scene, reveal implied intentions hidden in it, etc. The correlation of a song and a video in film manifests itself as an interconnection of lyrics and lip movements, gestures, actions of characters as well as visible images on the screen. It means that the translation of songs in films requires a certain share of synchronization. Chaume [12,43] suggests three types of synchronization relevant to film translation, i.e., phonetic, kinetic and isochrony. Phonetic (or lip) and kinetic (body movement) synchrony are highly relevant in the translation of diegetic songs. Here, the lyrics sung by the voice which delivers the translation must match the lip and body movements of the character. Isochrony (or duration synchrony) presupposes that the duration of stanzas or lines sung in the source film would coincide with the ones in translation. It provides for a better perception of the final result and eliminates possible confusion. Isochrony is significant for dubbing as well as for voice-over and subtitling. It should be mentioned, that so-called content synchrony $[4,359]$, i.e., the synchronization of lyrics and the on-screen situation, apart from the body/lip movements, is no less important.

At the content level, the correlation of a song and a video in a film exposes itself in the interdependence of lyrics and a film plot. Song lyrics contain keywords and/or phrases that serve to convey the abovementioned artistic purpose. Moreover, some particular words and expressions used in lyrics can literally illustrate the video sequence. In terms of translation, it is especially important for diegetic songs in musicals and animation films. However, lyrics used in non-diegetic songs also provide additional or extra information and, hence complements the video sequence. As far as a song is a part of multimodal and performative film text, i.e., visual elements here construct the semantic meaning of a song, a discrete translation of lyrics results in irrelevant or incomplete TT $[3,193]$. The lack of coherence to the overall communicative situation would probably cause a certain deal of incongruity between a song and the context of a film.

There is also a correlation between a song and a video in film in terms of the audial perception, which depends on the voices of voice actors and song performers in translation. The voice and its quality in the multimodal translation is an essential part of the process, as important as translation of the verbal content since its choice has considerable influence on the audience's perception of the whole film $[3,196]$. It is important to avoid situations when different voice actors represent a character's voice in narration and singing or lyrics reciting. It can lead to a distorted perception of a character in general and the whole film in particular.

Moreover, there is a range of additional challenges of extralinguistic origin. These are different factors tied to cultural peculiarities of a song used in a film, i.e., relation to personalities (author of the lyrics, composer, performer(s)), situation of creation, context of performance, relation to specific cultural or historic events or historical periods, etc. In the same way, lyrics containing cultural references comprise a huge translation challenge. In most cases, intertextual layers integrated into a film in a form of songs are lost on a foreign audience in translation [13, 422]. Another issue that influences translation strategy is song recognizability in a target culture. All these factors add up to the connotative meaning of lyrics and can be crucial to the understanding of a film. Of course, there are some other constraints in song translation in films, such as financial ones. Song translation, especially a singable translation, requires additional knowledge in musicology, vocal skills, human and technical resources and time, and thus, more expenditures.

\section{Functional correspondence of film songs in translation}

Theoretically, an adequate translation of a song presupposes the creation of its TL version that would recreate the integrity of musical, textual and performative components of a SL version. However, this ideal is hardly achievable in practice, and, in fact, it is not even 
required in most cases. The number of challenges and constraints associated with the translation of songs in films advocates for the need for functionality and consideration of the problem in terms of Skopos theory. First and foremost, the adequacy of a song translation depends on a pragmatic function that this song has to fulfil in a specific episode. The pragmatic function of a song in a film is formed by a set of characteristics comprised by the interconnection of lyrics, music, and video. In each case, the combination of characteristics is unique, with different dominant and supplementary elements. Thus, each particular case demands a specific approach, consideration of communicative situation and decision as to the translation strategy. The translator focuses on the dominant factor that forms the function of a song in a film, also keeps supplementary ones under review. Overall, approaching a song translation in films, Low's $[9,194]$ definition of 'accepted accuracy' seems to be proper to the occasion since it presupposes a certain level of 'manipulation' with the source text.

Based on the discuses above, it is possible to suggest five criteria (viz. pragmatic, semantic, stylistic, cinematic, and aesthetic) to assess a song translation in a target film. The criteria consider whether the dominant characteristics of a source song correspond to the target one in translation on the aforementioned levels. However, the suggested structure prioritizes the pragmatic level, as it is a necessary prerequisite of an adequate translation. Hence, the pragmatic correspondence means that a song in a target film fulfils the same function as a song in a source one and is appropriate to the communicative situation of an episode. Semantic correspondence signifies that a song in translation renders the content and meaning of the source song. It presupposes that the target film audience can easily grasp the main idea of the source lyrics. Stylistic correspondence requires a song in translation to possess poetic and prosodic characteristics that are close to a source one. It means that a target lyric has a rhyme scheme, rhythmical structure, and is potentially singable. Cinematic correspondence presupposes that a target song does not break an interconnection with a video sequence inherent to a source song. It means that a target song is performed in the similar way it was performed in the source film, and is fully synchronized with a visual, audial, and semantic component of a film. Aesthetic correspondence is purely extralinguistic and presumes that a target song possesses an artistic, emotional, and cultural value of a source one. On this level, a target audience should perceive a translated song as if it is an original. Aesthetic correspondence is a relatively subjective category, but it is safe to say that it is achieved when there is a correspondence on all other levels.

The potential possibilities to achieve correspondence on pragmatic, semantic, stylistic, cinematic, and aesthetic levels depend on different factors, however the primary one is a particular translation technique used for recreation of a source song (Table 1).

Table 1. Correlation of the song translation techniques and levels of the source and target song correspondence.

\begin{tabular}{|c|c|c|c|c|}
\hline $\begin{array}{l}\text { Levels of } \\
\text { corresnondence }\end{array}$ & \multicolumn{4}{|c|}{ Translation techniques } \\
\hline Pragmatic & $\begin{array}{c}\text { Zero } \\
\text { translation }\end{array}$ & \multirow{4}{*}{$\begin{array}{l}\text { Interlinear } \\
\text { translation } \\
\text { (subtitling) }\end{array}$} & \multirow{5}{*}{$\begin{array}{l}\text { Interlinear } \\
\text { translation } \\
\text { (voice-over) }\end{array}$} & \multirow{5}{*}{$\begin{array}{l}\text { Adaptation } \\
\text { (dubbing) }\end{array}$} \\
\hline Semantic & & & & \\
\hline Stylistic & & & & \\
\hline Cinematic & & & & \\
\hline Aesthetic & & & & \\
\hline
\end{tabular}

In general, several conventional techniques are used in film translation, viz. subtitling, voiceover and dubbing. However, the general strategy of a film translation does not necessarily coincide with the way songs are rendered in a target film. Three basic techniques that are applied to the rendering of songs in films are zero translation, interlinear translation of source lyrics and overall adaptation of source lyrics. Zero translation is a transfer of a source musical 
composition in a target film in its original form. Interlinear translation presupposes the rendering of source lyrics into the target language. The target text is then given in subtitles or as a voice-over recital. Another technique is an adaptation of the TT lyrics to the ST music taking into account the communicative situation of an episode. Mostly, lyrics adaptation is produced when a song is intended to be dubbed, though a target lyric is singable and is synchronized with the video sequence. Let us consider these techniques in details and examine the cases illustrating the ways different levels of correspondence are achieved.

\subsection{Zero translation}

Zero translation is the most widespread technique used for non-diegetic songs rendering in films. An evident advantage of the technique is that it does not require any additional resources - either financial or human - though is beneficial for the studio providing translation. On the other hand, the technique has a significant drawback, since it cannot account for comprehensive recreation of a source song potential in the target film. Therefore, zero translation is rarely used for diegetic songs rendering, especially in musicals and animated films, as the technique does not recreate the pragmatic function of a source song, i.e., to serve as the narration. For example, a screen version of the musical 'Cats' [14] available on Ukrainian streaming services provides dubbed dialogues, however the songs are given in zero translation. The target viewers are unable to follow the film plot and fully understand its sense. Also, compared to other techniques, zero translation is less efficient when background song's lyrics serves to emphasize emotional state, express feelings or thoughts of a character, designate transformations of a plot or a character's personality, provide a summary of particular events, create comic effect, etc. For instance, the 2020 series 'Home Before Dark' [15] employs a lot of songs to illustrate or emphasize an action in the video sequence. Here, at the end of the first episode, the viewers can hear Carrie Underwood's song 'Champion' sung in the background by the children chorus 'PS22 Chorus'. Lyrics of the song: "I am invincible, unbreakable // Unstoppable, unshakeable // They knock me down, I get up again // I am the champion, you're gon' know my name // You can't hurt me now, I can't feel the pain // I was made for this, yeah, I was born to win // I am the champion" combined with the video sequence expresses the emotional state and determination of the main character - a girl named Hilde - to unearth the truth behind a mysterious disappearance of a child that happened in the town many years ago. The series is translated via voice-over into Ukrainian, however songs are introduced using zero translation. Zero translation of non-diegetic songs is also found in animation films (even though, an adaptation technique is usually used for rendering songs in films aimed at a children's audience). For example, in the animation film 'Wreck-It Ralph' [16] the song 'Shut Up and Drive' by Rihanna is played in the background and accompanies an episode where the protagonist, Wreck-It Ralph, teaches his newly-obtained friend Vanellope to drive a racing candy car. The lyrics illustrate the video sequence and makes the whole situation quite humorous: "Cause it's 0 to 60 in 3.5 // Baby, you got the keys // Now shut up and drive, drive, drive...." In translated films, the target audience relies on the emotional potential of the music, while a considerable amount of semantic information would be lost in translation.

However, there are situations when zero translation is, actually, the best decision in terms of pragmatic correspondence. These are the cases when foreign songs (different from the country of the film origin) are used intentionally to create a specific atmosphere or emphasize authenticity. For instance, the film "The Legend of Tarzan" [17] employs the songs of an indigenous African tribe. The songs are diegetic and are sung by the tribe members during the celebration in the course of the film. The film is dubbed in Ukrainian, though the songs are rendered via zero translation. Thus, the authentic atmosphere of an episode is recreated in the Ukrainian film. Likewise, zero translation can recreate the pragmatic function of a 
source song when it is widely known and recognizable in a target culture. Such world-famous songs as 'Jingle Bells', 'Last Christmas' (originally performed by 'Wham!') or 'Let It Snow' (originally performed by Frank Sinatra) are used in plenty of American movies featuring Christmas. For instance, 'Last Christmas' is heard in the background in 'The Holiday' [18] and 'Let It Snow' in 'Love, Rosie' [19]. In the film 'Mean Girls' [20], there is an episode, where the group of female characters perform 'Jingle Bells' on stage as their number in a school talent show. In all cases, the songs in Ukrainian films are presented in zero translation. Still, emotions and associations evoked by these songs are pretty similar to both source and target audience due to the processes of globalisation and pervasiveness of American culture.

Also, it seems that zero translation is effective in situations when the primary function of a song in a source film is to create an atmosphere and specific vibe of a particular scene. Such genres as action, adventure, thriller, horror, etc. employ songs to evoke an emotional response and rely more on the prosodic features of the music rather than on the semantic potential of the lyrics. In the action film 'Guns Akimbo' [21] non-diegetic songs that illustrate video sequences are used to create comic effect and emphasize the surreality of the situations. For instance, a bloody gun battle scene is accompanied by the song 'You Spin Me Round (Like a Record)' by '3Teeth'. Here the combination of a cheerful melody and a gore scene plays a more important role than the content of the lyrics. Since the song has been re-released and remixed numerous times, its tune is easily recognized by Ukrainian viewers. Though, zero translation of the song used in the Ukrainian version of the film potentially achieves the same pragmatic function.

In fact, the recognizability of a song by the target audience as well as its connection to extratextual reality are the factors that rationalize the prevalence of zero translation. For instance, the song 'See you again' was used in the film 'Furious Seven' [22] as a tribute to Paul Walker, one of the lead actors of the 'Fast \& Furious' franchise, who tragically died in a car crash. The song is heard at the end of the film and accompanies the footage of Brian O'Conner's (Paul Walker character) happy ending. The song lyrics are emotive, it implies grief for the lost friend and acceptance of the loss: "It's been a long day without you, my friend // And I'll tell you all about it when I see you again // We've come a long way from where we began // Oh, I'll tell you all about it when I see you again // When I see you again." A short dialogue precedes the song: "You aren't going to say goodbye?" («Не хочеш nопрощатися?») and the protagonist (who was a close friend of Paul Walker and his character in the film as well) answers: "It's never goodbye" («Ще побачимося.»). It means that the lyrics are incorporated into the plot and unfolds the protagonist's thoughts. In the dubbed Ukrainian version of the film, the song is played in its original version. Although it is worth mentioning, that the song was accepted by Ukrainian viewers and gained popularity in Ukrainian music charts, not least due to the fame of the franchise and the target audience awareness of the extratextual context.

It is possible to conclude that zero translation as a technique for songs translation in films has several drawbacks. The lyrics in translated films are presented in the language of the original, hence it is impossible to consider the correspondence on semantic or stylistic levels. The lyrics content and connections to the plot would be lost in target films unless the target viewers possess the knowledge of the original language. It is hardly possible to consider correspondence on the stylistic or cinematic levels since the original song is not indeed recreated but rather transferred into the target film. Thus, it preserves the characteristics of the original song and does not provide a genuine target material appropriate to draw a comparison. The same applies to the aesthetic correspondence. Nevertheless, zero translation technique can achieve the pragmatic correspondence, mostly in the following cases: the lack of translation proper is determined by the film concept; a source song is widely known and recognized by the target audience; the primary function of the song is to convey a particular feeling or mood of a particular scene. 


\subsection{Interlinear translation}

Interlinear translation of lyrics is usually presented in films in subtitles or as a voice-over recital. This kind of translation tends to focus more on the semantic correlation than on the music and poetic qualities of a source song. Translation of lyrics in subtitles has several significant advantages, i.e., its low price (compared to voice-over and adaption for dubbed translation) and ability to render the content of lyrics, yet preserving the original sounding $[23,192]$. However, a drawback of a subtitled song in a film is a need to follow an action on the screen and read the subtitles simultaneously, which may be burdening for the target viewers. The latter also eliminates the possibility to achieve the correspondence on the cinematic level. Quite often interlinear translation of lyrics in subtitles is used for rendering songs in musicals aimed at the adult audience. For instance, this technique was used to render an original song 'City of Stars' used in the musical film 'La La Land' [24]. The song is sung in the movie twice and each time the lyrics portray the character(s) state of mind and feelings. Firstly, the song marks the lead character hopes for the future and careful optimism regarding his relationships with the main heroine. Later in the film, the song is sung again in duet, when the relations of characters are on the verge since both of them makes a choice in favour of their careers and professional ambitions. Despite several minor inaccuracies in translated version ("A rush" - "Турбота"; "A look ... To open the world and send it reeling" “Погляд...Що світ нам відкриє, У нього душа полетить”) it is possible to conclude, that it faithfully renders the content of the original song. The position and wording of the key lines - "City of stars" - "Мiсто зірок" - are also preserved in translation. Considering the stylistic features of the source lyrics and its translation, it is evident that the latter cannot serve as its singable version, as it does not follow the rhythmical structure of the original. In general, the translated version is rather literal. However, it is worth mentioning, that the use of variant equivalents ("smokescreen" - "задимлених"; "says" - "промепоче"), occasional rhymes (I don't care if I know // Just where I will go - Байдуже мені // куди niдy я в ичі дні), and inversions ("Все зрозумів, коли тебе уперше обійняв я", “Бо потрібно лиш почуття ие мені") benefit the translation and endow it with lyrical sounding.

In the aforementioned movie, the songs are introduced like the 'real' songs that are sung by characters. Though, there are cases, where songs are incorporated into the film's plot on a deeper level. For example, in the musical series 'Zoey's Extraordinary Playlist' [25] the plot revolves around Zoey Clarke who, after an accident during the MRI, develops the ability to hear the thoughts of people as songs. Hence, songs develop a story-line, and there are at least four song-and-dance numbers per episode. It is obvious that voice-over translation or dubbing of all the songs would skyrocket the cost of the Ukrainian localization. Thus, the crowdfunded studio 'GoolPictures' opted for interlinear translation of lyrics in subtitles (while the dialogues are given in a voice-over). One of the first songs the protagonist hears is 'Help' by 'The Beatles' performed by the strangers on the street she walks and on the tram she rides. It designates the beginning of the protagonist's journey into the innermost thoughts of other people as well as conveys the idea that any person carries a burden of unsaid problems and miseries while desperately longing for help. The distinctive feature of song performance in the series is that different lines are sung whether by a male character, a female character or by the chorus. As in the previous example, here interlinear translation renders the content of the source song. The keyword - "help" - is rendered in two different grammatical categories in translation (third person plural "допоможimb" and second person singular "допоможи"), however, the positioning is preserved. It is also important, that the translation accounts for the gender of a singer and provides Ukrainian verbs with appropriate endings: "When I was younger.." - "Коли я була молодша...", “And now I find I've changed my mind" - "Тепер я передумав". Though, stylistic features of the original are mainly disregarded in translation. The choices of Ukrainian equivalents are either too literal or does not possess emotive and connotative value of the original ("opened up the doors" - "дверi 
відчинив; "vanish in the haze”- “зникла в тумані"; "self-assured”- “запал”). It is worth mentioning, that such cases are especially challenging due to the usage of arrangements of popular songs. The fact affects an aesthetic perception of songs, and the whole film or series in particular, by the target audience. Genres of the original songs, their original performers compared to arrangements used in series, and even the stories behind the creation of original songs complement the plot with additional nuances. It is expected, that the source viewers would gain aesthetic pleasure of recognizing the songs and linking them to the primary origins. Though, there is no guarantee that Ukrainian viewers possess the necessary extralinguistic information to perceive the songs as the source audience would do. Interlinear translation in subtitles provides the target viewers only with the content needed for the comprehension of an episode. As well, interlinear translation of songs in the voice-over does the same in described situations. For instance, the 'Pitch Perfect' [26], a film about a university acapella group, is filled with various diegetic songs performed by the actors. Most of the songs in the film belong to the popular culture and are easily recognizable by the source viewers. In general, lyrics do not contribute to the film plot, the focus is rather on the choice of these songs (popularity, performers, time of release, etc.) and the way these songs are performed in the film (pot-pourris, arrangements, etc.), e.g., the group performes an arranged pot-pourri of 'Price Tag' by 'Jessie J' and 'Don't You (Forget About Me)' by 'Simple Minds' during the final contest: "We just wanna make the world dance // Forget about the price tag // Won't you come see about me? // I'll be alone, dancing, you know it, baby." The Ukrainian version of the film (including the lyrics) was translated via voice-over (the lyrics are recited, not sung): "Ми хочемо, щоб світ танцңював // Забувши про ціну // Хочеш побачити мене? // Я танцюватиму, ти ие знаєш, любий”. The positive feature is that both narration and lyrics were done via multi voice-over, and the same voice actors revoiced the dialogues and lyrics in the Ukrainian version, thus it creates a natural sounding and allows to easily distinguish characters in the target film. However, there is no guarantee that Ukrainian viewers would be able to recognize all of the songs used in the film and perceive the cultural connotations related to them. Undoubtfully, the recreation of the culture-bound implications of a source song is an enormous translation challenge. However, in most cases, the interlinear translation provides target viewers with the content of the lyrics.

Interlinear translation can be particularly useful when the primary function of a song in a film plot is determined not by its musical quality or cultural implications, but rather by the lyrics. Quite a remarkable example is found in the French movie 'The Translators' [27]. The plot is about nine translators confined in a bunker beneath a French manor to produce a translation of the third book of a best-selling trilogy on nine languages at the same time to prevent leakage. The characters speak French in the course of the film, but in one scene one of the characters proposes a toast for the brotherhood of nations and starts to sing a song in English. The other characters join him in a joyful chorus. They sing a verse from the 'What the World Needs Now Is Love', a 1965 popular song performed by the American singer Jackie DeShannon: "What the world needs now is love, sweet love // It's the only thing that there's just too little of // What the world needs now is love, sweet love // No not just for some, but for everyone." While the whole movie is dubbed in Ukrainian, this episode is translated in a voice-over: «Зараз світу бракує любові, любові. Це єдине чого завжди нам бракує. Зараз світу бракує любові, любові. І не комусь одному, але нам усім». The voice-over is done by a single male voice artist, thus it creates an asymmetry on the cinematic level, as the target viewers can clearly see and hear that all the characters are singing. Yet in this case, the primary function of a song is to introduce the specific statement. In the subsequent scene, a publisher gets a threat message stating that the first ten pages of the novel were leaked on the net. The note ends with the very words that were sung the evening before: 'What the world needs now is love, sweet love'. Later, the publisher confronts translators and recites the lyrics addressing to the character who started the song: "What the world needs now is 
love, sweet love", that was also rendered in a voice-over: «Та зараз світу бракує любові, бракуе любові». The main focus is to draw the attention of the target viewers to the exact wording of the lyrics, which is important for comprehension of the future plot twist. In the Ukrainian version of the film the wording is preserved, thus the pragmatic function of the song is recreated in translation.

The choice between two options of the lyrics' interlinear translation representation in a target film - in subtitles or as a voice-over - is stipulated by many factors, including the financial opportunities of a localization studio, preferences of a target broadcasting media, and an aim of a target text. It is not uncommon when both options are available for target viewers. For instance, there are two Ukrainian translations of the film ' 8 Mile' [28], a voiceover done by the TV channel 'Novyi Kanal' and a subtitled version provided by the streaming service Netflix. The film depicts an attempt of the rapper B-Rabbit (portrayed by actual rapper Eminem) to launch a career in hip hop, thus the film features a number of rap songs, e.g., a final rap battle aimed to unmask and humiliate an opponent. In both cases, Ukrainian interlinear translation renders the content. However, there are noticeable differences on the stylistic level. Lyrics of a rap song has specific stylistic features - the vast use of colloquial, informal, slang words, and obscene lexical units - though, this one is not an exception ("dude", "wanna", "dawg", "crook", "fuck"). Both translations are less expressive and more restrained in the choice of lexical equivalents. It is possible to notice that the voice-over version tends to neutralization, e.g., "fucking bum" - "безпритульний" (Cf. "безпритульний смердюк" in the subtitled version). Presumably, this is caused by the demands required of broadcasted productions on television. Compared to the voice-over version, the subtitled one is less literal and gives an impression of a natural colloquial speech. Moreover, the usage of rhyming words ("засудити" - "жити”, “щось" - "ось", "прикидається" - "стараються", еtс.) creates a rhythm in the subtitled version, which harmonizes with the beat of the song that is heard in the background. Nonetheless, interlinear translation presented in a voice-over has an advantage over subtitles - it does not distract the viewers from the video sequence. Thus, it can account for partial correspondence on the cinematic level, especially when the same voice actor revoices the character's narration and singing, as in the cases discussed above.

Another issue worth mentioning within the discussion of the problem is the target audience interest and engagement in the translation of the songs used in films. A prime example is the song 'Toss a Coin to Your Witcher' used in 'The Witcher' [29] series. The song is an original one, i.e., was written specifically for the show, and is regarded as the show's soundtrack. It is a diegetic one and is performed by one of the characters, a travelling bard Jaskier, in the second episode of the show. The song has become a viral hit not least due to its catchy tune. There are two Ukrainian translations of the series that were made by two independent crowdfunded studios - "SVOÏ production" and "Tak Treba Production". Both Ukrainian versions are voice-over translations. However, "SVOÏ production" studio introduced the song in its original version, while in the version by "Tak Treba Production" studio the song is subtitled. The lyrics of the song is Jaskier's attempt to portray Geralt, the Witcher, in a favourable light and persuade people to pay him for the work he does. It takes an ironical tone and is, in fact, a parody of medieval heroic ballads, e.g., "When a humble bard // Graced a ride along // With Geralt of Rivia // Along came this song"; "They came after me // With masterful deceit // Broke down my lute // And they kicked in my teeth // While the devil's horns // Minced our tender meat..." The subtitled version renders the content: "Коли несміливий бард // рушив топтати стезю, // в компанії Геральта з Рівї̈, // співав він пісню оиюю.”; “...І рушили за ним, // до хитрощів удавщись, // ...лютню мою зламали // у зуби зарядили // Коли чортячі роги // ту плоть мою кололи". However, the rendering of lines tends to literal translation, thus the imagery and ironical tone were not fully recreated in translation. This particular song has evoked a widespread reaction among the Ukrainian 
fans of 'The Witcher' franchise and led to the appearance of several amateur translations of lyrics, that are singable, e.g.: «Ваш скромний бард зустрів // В дорозі Відьмака. // Тож про Геральта з Ривї // Балада моя”. "Схопили і мене // Підступні вороги, // Понищили лютню // І в зуби дали. // Коли ж поцілив біс // Рогами в ніжний бік...» [30]. The case proves, that there is a public demand for the properly translated versions of songs used in films, which should be regarded by localization studios.

In general, interlinear translation as a technique for song translation in films displays a considerable potential. Since a source song can be still heard by the target audience, translated or recited lyrics supply a statement that gives a general understanding of a song content. When stylistic characteristics of a source song (its rhyme scheme, rhythmical structure, images, expressiveness, etc.) serve as a guideline and shape the target translation, target lyrics might as well match the music on a prosodic level and create a stylistic correspondence. Moreover, partial cinematic correspondence is possible, when interlinear translation is presented as a voice-over, especially in cases when the character is voiced by the same voice actor. Interlinear translation achieves a pragmatic correspondence in most cases and can be used as a basic technique of song translation in films.

\subsection{Adaptation}

The choice of a particular technique for rendering a song in a film by a localisation studio depends primarily on the available resources. Adaptation technique consumes more time and more resources compared to the above-mentioned ones. However, it is beneficial for the target viewers, as the target song is perceived as an original one. Adaptation of source lyrics for target film is usually used for translation of diegetic songs, especially in genres, where songs represent a crucial part of the plot, such as musical feature films, animated films and cartoons. Mostly, the children's audience shapes the demand for songs adaptation. For instance, dubbed Ukrainian versions of the Walt Disney Studio productions are the exemplary cases of the technique, e.g., the song 'Let It Go' from the animated film 'Frozen' [31]. The song is performed by the main character, princess Elsa, who flees her kingdom when the people discovered her magical powers - to control the snow and ice. The song marks the metaphorical reborn of the heroine as she unleashes her powers. The song in translation clearly reproduces the same idea. Though the key phrase of the song "let it go" transforms into "все одно" in translation, still, it renders the primary function: to show an acceptance of the situation and readiness to move on despite the hardships. Another phrase "The cold never bothered me anyway" is repeated several times in a source song. It was translated as "Та холодуя не лякаюся" and retains its positioning in the target version. The peculiar feature of the source lyrics is a vast usage of words denoting cold weather conditions (e.g., "snow glows white", "wind is howling”, "swirling storm", "frozen fractals", "icy blast", etc), which describe the video sequence and signify the inner state of the character. Translated version opted for variant equivalents (e.g., "білий сніг”, “вітер-хуга”, “віхола”, "зима"), which render the appropriate images. The target song is a singable one, the translated lyrics matches the original music. Moreover, the pattern of rhymes in translation follows the source one (e.g., AABB here: "inside" // "tried" // "see" // " ве" - "зла" // “змогла" // “доведи” // “завжди” or ABAB here: "gone” // "day" // "on" // "anyway" “я” // "пишаюся" // “зима" // “лякаюся”). Though, it is safe to say, that there is a stylistic correspondence between the source and target song. In terms of phonetic and duration synchrony, the target lyrics are fully synchronized with the video sequence. However, it is worth mentioning, that one line of the translated song, i.e., "На волю шугне воно" is sung with a faster pace, than other lines. Though, it can cause difficulties in comprehension of the lyrics in this line. In most cases, the content correspondence is also preserved in translation. For instance, the lines "The snow glows white on the mountain tonight // Not a footprint to 
be seen" illustrates the video sequence, as the viewers can see a wide shot of gloomy mountains covered in snow and the heroine walking alone. The translation "Цей білий сніг дику гору обліг, // Навіть сліду тут нема" fully corresponds to the on-screen situation. The lines "When I'll rise like the break of dawn" are accompanied by the footage of Elsa covered in shiny sparkles as she changes her gown into a new one. Thus, a sense development in translation " $Я$ заграю, немов зоря" also renders the connection with the video, as the heroine is literally beaming as a shining star. However, in one situation the relation between lyrics and video is lost. While singing "My soul is spiraling in frozen fractals all around // And one thought crystallizes like an icy blast", Elsa creates her ice castle and the frozen fractals (snowflakes) and crystals (walls and spires of the castle) are shown on the screen. The translated version of these lines "Хай сила рине в землю - так бажаю я! // Як віхола заклубочиться хай душа моя!" does not preserve the interplay of words and video sequence. However, the translation of other lines creates additional connections between lyrics and the on-screen situation. For example, the heroine approaches an abyss, while singing the line "I страхи мої безодні" and creates an ice bridge over the abyss to cross it while singing "шо вільна перейти межу". This can be regarded as compensation for the loss. In translated film, Elsa was voiced by an actress Alina Protsenko, while the songs were performed by a singer Shanis (though in the source film the character was voiced by a single voice actress Idina Menzel). However, the voices bear resemblance to each other, thus the difference is hardly noticeable in the target film. It is possible to conclude, that cinematic correspondence is achieved. Moreover, the Ukrainian version of the song is available on various music streaming services, such as YouTube Music and Deezer. It proves the song popularity and favourable perception by the Ukrainian audience and its functioning in the target culture as an individual song apart from the film itself. Thus, it gives grounds to affirm, that there is a correspondence on the aesthetic level as well. Undoubtfully, the high-quality adaptation of lyrics and performance of songs in a dubbed version of a film makes the overall perception aesthetically pleasing, since it eliminates the foreign element. In such cases, a target film is a coherent whole, which is favourably perceived by the Ukrainian public in general.

\section{Conclusions}

This study has shown that a song in a film can be defined as a musical composition - an integration of the textual and musical modes of content and expression - that accompanies a video sequence in a film, is performed in a predefined way and is subordinate to certain artistic purpose. The main challenge of a song translation within the frameworks of a film is the multimodal nature that stipulates for the predefined visual, acoustic, temporal and spatial translation constraints.

Translators work with the lyrics since it is the only element that is subject to changes within a process of a song translation in films (the music, video sequence and possible relevant extralinguistic references are invariable). Thus, a pre-translation analysis of lyrics should consider its interconnections with 1) music on prosodic, poetic, and emotional levels; 2) video sequence on content, visual, and audial levels; 3) culture-bound implication and relations. It reveals the key characteristics of a particular song in a film and, hence, its pragmatic function. A pragmatic function, which a source song fulfils in a source film, is an ultimate guideline that helps to define a translation method. Thus, as the functions vary, each song within a film should be considered as a separate translation case.

The adequate translation of a song in a film presupposes a correspondence of the key characteristics of a song in a source and target film on the pragmatic, semantic, stylistic, cinematic, and aesthetic levels. The levels are placed in a hierarchical order, i.e., the translation adequacy here allows deviations or lack of correspondence on the other levels 
unless the pragmatic correspondence is preserved. There is a correlation between a translation technique applied to a song in a film and a potentially achievable level of correspondence. The paper proves that the recreation of songs in film is a translation compromise within an interrelation of multimodal systems and their components.

Clearly, the functional approach to song translation in films provides a room for manoeuvre, since the preferential position of the pragmatic level of correspondence advocates for the flexibility of the translation strategy. It means, that any translation technique - zero translation, interlinear translation, and adaptation - can potentially recreate a source song function in a target film. Suggested levels of correspondence of a source and a target song in film sketch an approach that can be used to single out dominant characteristics of a specific song, to define whether these dominant characteristics are preserved in translation, to draw a conclusion on particular ways used to recreate specific features of a source song in translation and to conclude whether a target song is adequately rendered within a film. An advantage of this approach is the fact, that it does not consider source lyrics in isolation, but regards other factors, that influence the translation process. Undoubtfully, further analysis employing songs with specific characteristics used within the films of particular genres will enrich the suggested approach. There is abundant room for further progress in determining the role and ways of recreation of culture-bound implications in lyrics, determination of minor and major losses in translation of songs in films, etc.

\section{References}

1. Ch. Bosseaux, in K. Malmkjær and K. Windle (ed.) The Oxford Handbook of Translation Studies, 132-141 (OUP Oxford, 2011)

2. L. Pérez-González, Audiovisual Translation: Theories, Methods and Issues, 356 (Routledge, 2014)

3. L. Desblache, Music and Translation: New Mediations in the Digital Age, 417 (Palgrave Macmillan UK, 2019)

4. R. Mayoral, D. Kelly, \& N. Gallardo, Meta, 33 (3), 356-367 (1988).

5. J. Franzon, Translator, 14, 373-399 (2014).

6. R. Apter, Meta, 30 (4), 309-319 (1985).

7. M. Traven, in D. L. Gorlée (ed.) Song and Significance: Virtues and Vices of Vocal Translation, 103-120 (Rodopi, 2005).

8. H. Golomb, in D. L. Gorlée (ed.) Song and Significance: Virtues and Vices of Vocal Translation, 121-161, (Rodopi, 2005).

9. P. Low, in D. L. Gorlée (ed.) Song and Significance: Virtues and Vices of Vocal Translation, 185-212 (Rodopi, 2005).

10. L. Alonso \& P. María, Transletters, 2 (3), 75-108 (2019).

11. Ch. Bosseaux, in H. J. Minors (ed.) Music, Text and Translation, 81-92 (Bloomsbury Academic, 2013).

12. F. Chaume, in P. Orero (ed.) Topics in Audiovisual Translation, 35-52 (John Benjamins Publishing Company, 2004).

13. R. Johnson, in L. Pérez-González (ed.) Routledge Handbook of Audiovisual Translation, 418-435 (Routledge, 2019)

14. T. Hooper, Cats [Motion picture] (Universal Pictures, 2019)

15. D. Fox, D. Resnik, Home Before Dark [Television series] (Apple TV+, 2020)

16. R. Moore, Wreck-It Ralph [Motion picture] (Walt Disney Studios Motion Picture, 2012)

17. D. Yates, The Legend of Tarzan [Motion picture] (Warner Bros. Pictures, 2016)

18. N. Meyers, The Holiday [Motion picture] (Universal Pictures, 2006)

19. Ch. Ditter, Love, Rosie [Motion picture] (Lionsgate, 2014)

20. M. Waters, Mean Girls [Motion picture] (Paramount Pictures, 2004) 
21. J. L. Howden, Guns Akimbo [Motion picture] (Madman Entertainment, 2020)

22. J. Wan, Furious Seven [Motion picture] (Universal Pictures, 2015)

23. N. Bidasyuk, Philological Discourse, 5, 186-194 (2017)

24. D. Chazelle, La La Land [Motion picture] (Lionsgate, 2016)

25. A. Winsberg, Zoey's Extraordinary Playlist [Television series] (NBC, 2020)

26. J. Moore, Pitch Perfect [Motion picture] (Universal Pictures, 2012)

27. R. Roinsard, Les traducteurs [Motion picture] (Trésor Films, 2019)

28. C. Hanson, 8 Mile [Motion picture] (Universal Pictures, 2002)

29. L. Sch. Hissrich, The Witcher [Television series] (Netflix, 2019)

30. O. Andorsova, Toss a Coin to Your Witcher (Ukrainian cover), URL: https://www.youtube.com/watch?v=KnNxsm3uJyk\&ab_channel=Eileen (2020)

31. Ch. Buck, J. Lee, Frozen [Motion picture] (Walt Disney Studios Motion Pictures, 2013) 